\title{
The Billund delta: a possible new giant aquifer in central and western Jutland
}

\author{
Erik S. Rasmussen, Karen Dybkjær and Stefan Piasecki
}

The search for new, deep-seated drinking water resources in Denmark has increased significantly during the past five years as a result of the discovery of excessive amounts of nitrate, pesticides and other pollutants in shallow groundwater boreholes (e.g. Nygaard et al. 2004, this volume). To find and map these aquifers, a multidisciplinary sequence stratigraphic approach has successfully been applied to the Miocene deposits of southern Jutland, where especially the Odderup and Ribe Formations are known as a main aquifer for drinking water from several test wells (Rasmussen et al. 2002).

Recently, a more systematic study of the Miocene succession in central and western Jutland has been initiated by the Geological Survey of Denmark and Greenland (GEUS) under contract with local authorities. It includes detailed sedimentological descriptions of outcrops, sedimentological and

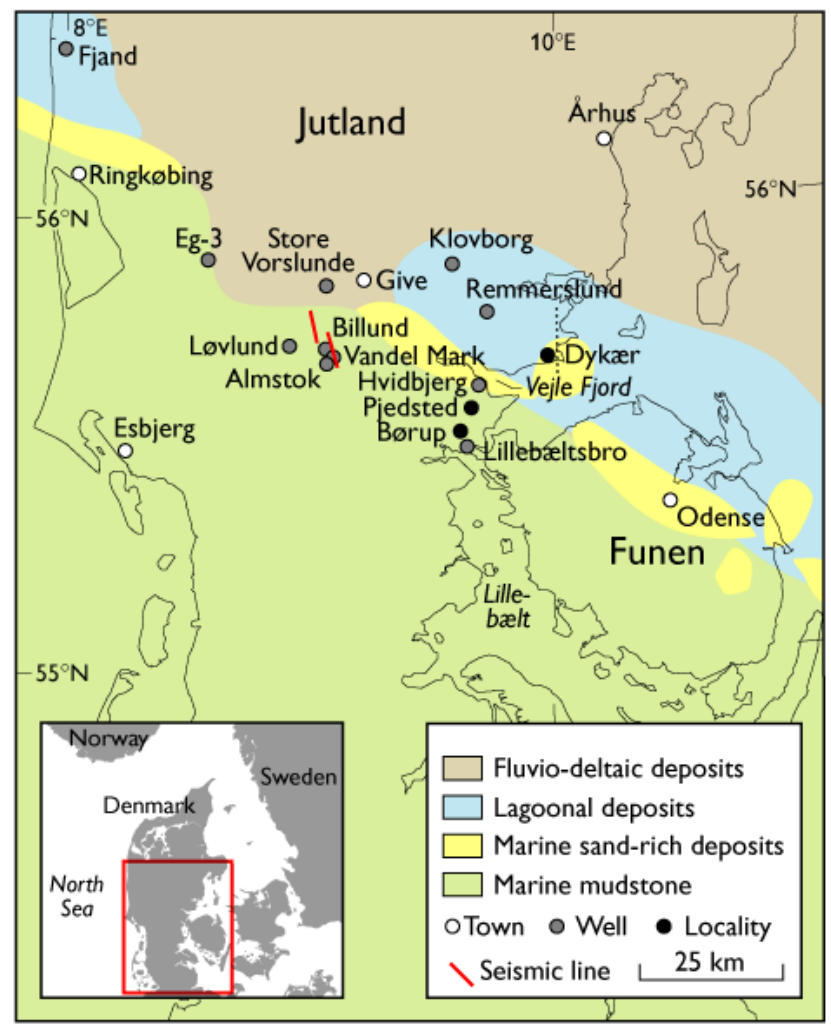

Fig. 1. Map of southern Jutland showing palaeoenvironments of the Billund delta, the location of boreholes and the seismic section mentioned in the text. log-interpretations of new stratigraphic boreholes and interpretation of new high-resolution seismic data (Fig. 1). A number of outcrops and wells have been studied palynologically, resulting in a detailed dinoflagellate cyst stratigraphy and in palynofacies interpretations. The results of these studies have been integrated in the regional geological and stratigraphic model (Fig. 2). Two new aquifers have been discovered: the Bastrup sand and the Billund sand. The Bastrup sand has already been exploited as a main aquifer in central and southern Jutland, and has been referred to either the Ribe or Odderup Formations. However, new stratigraphic results reveal that the Bastrup sand is a separate unit in the Miocene succession. The Billund sand is a deep-seated aquifer located more than $100 \mathrm{~m}$ and often more than $150 \mathrm{~m}$ deep, and is therefore not penetrated by standard water supply wells which rarely reach $c .100 \mathrm{~m}$.

The Billund sand was first revealed by multichannel seismic data deriving from former oil-exploration carried out in

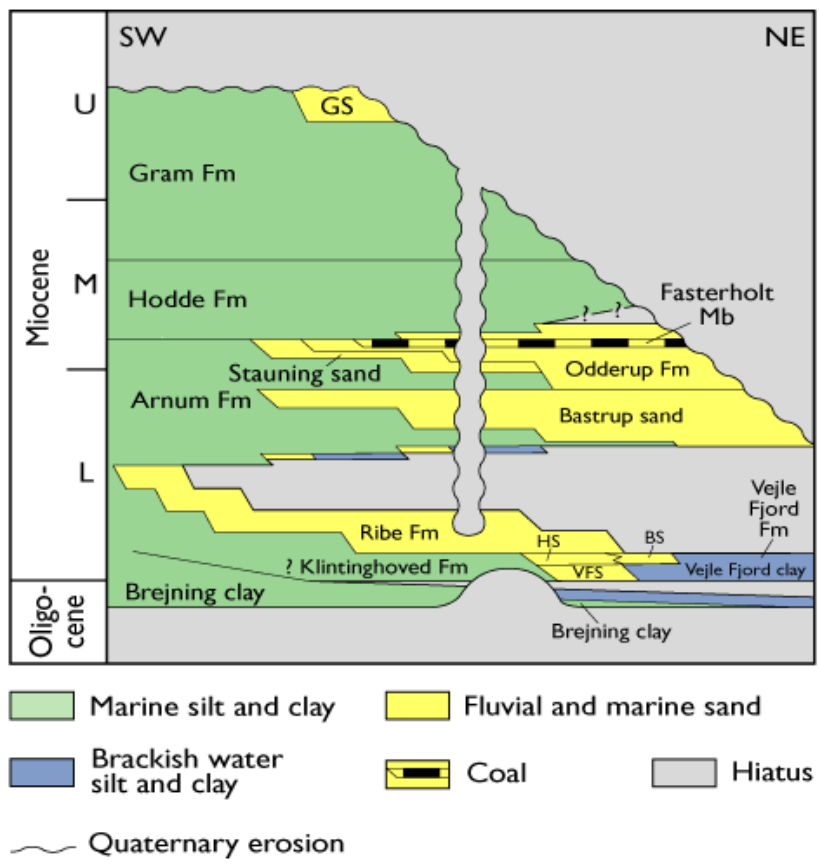

Fig. 2. Lithostratigraphy of the Miocene succession in Jutland compiled from Larsen \& Dinesen (1959), Rasmussen (1995), Dybkjær \& Rasmussen (2000) and Rasmussen et al. (2002). BS, Billund sand; GS, Gram silt/sand; HS, Hvidbjerg sand; VFS, Vejle Fjord Sand Member. 
$S$
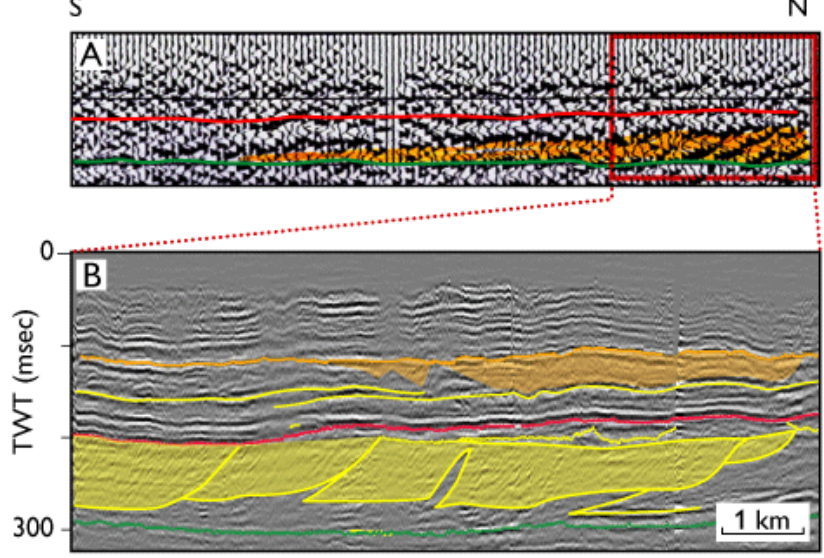

Fig. 3. Two seismic sections from the Billund area. A: the old multichannel seismic line DCJ-05. B: the new shallow seismic line GI01 (courtesy of COWI A/S). The red framed area in Fig. $3 \mathrm{~A}$ corresponds to the section shown in Fig. 3B. The clinoformal reflection pattern is indicated in yellow. the Billund area (Fig. 3A). The resolution of these seismic data is very poor, but one interpretation of the dipping reflectors (clinoforms) seen in Fig. 3A was of a delta complex. This agrees with outcrop studies along the fjords of eastern Jutland which suggest that a spit complex was deposited in this area during the Early Miocene. The Billund sand was tested by the Vandel Mark well in 2001, which penetrated $c .40 \mathrm{~m}$ of sand at a depth of $200 \mathrm{~m}$. The presence of a regional major sand body was later confirmed by new high-resolution seismic data and by the Billund and Løvlund wells in 2002. The Billund well penetrated $50 \mathrm{~m}$ of medium- to coarse-grained sand, and chemical tests of the water quality were good. However, a water supply well at Fjand in western Jutland has had problems with so-called 'brown water' - water enriched in organic matter (humus). Saline water may also be expected close to older deep-seated faults.

This paper summarises the results of a mapping programme of the Billund sand initiated in the summer of 2003.

S

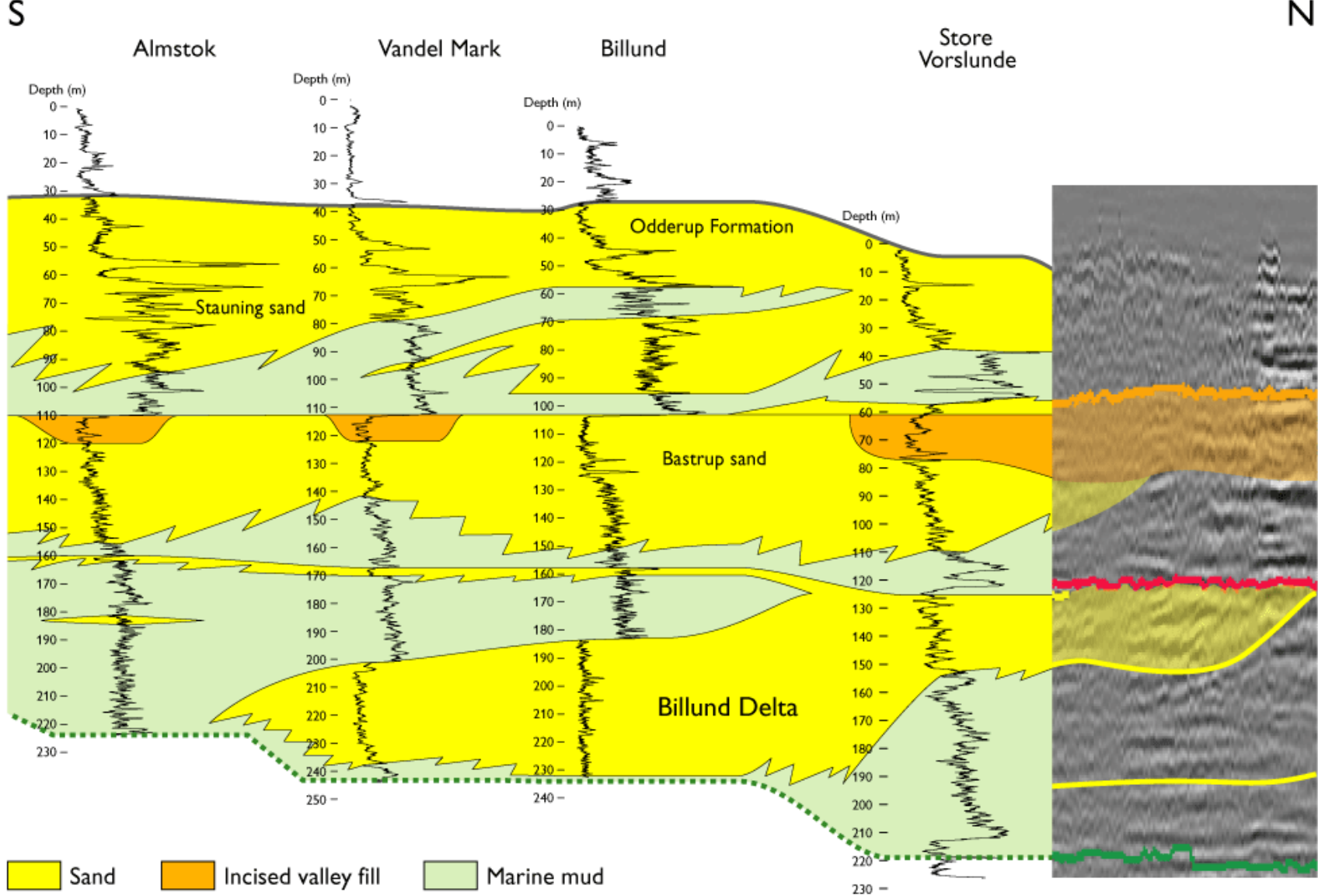

Fig. 4. Correlation panel of four boreholes, with gamma-ray log signature, trending N-S in the Billund area. The seismic section adjacent to the Store Vorslunde well shows the correlation of a clinoformal reflection pattern with sand. Note that the Billund delta pinches out between the Vandel Mark and the Almstok wells. Seismic data courtesy of COWI A/S. 


\section{The Billund delta}

The Billund sand represents a major Early Miocene delta prograding southwards from Norway into the Danish area. The study of the Billund delta includes interpretation of seismic data, lithological descriptions and interpretation of logs from new boreholes, sedimentological descriptions and interpretation of outcrops, dating and correlation of the succession by biostratigraphy (mainly dinoflagellates) and finally interpretation of the depositional environment based on palynofacies. Integration of these disciplines has resulted in a robust geological model for the delta that provides a basis for the prediction and location of good reservoir rocks suitable as aquifers for drinking water.

\section{Seismic mapping}

In order to map the extent and thickness of the delta, seismic data from both the North Sea and Jutland have been used. Based upon the study of the seismic data an isochore map of the delta has been constructed. The delta extends from $50 \mathrm{~km}$ west of the present-day west coast of Jutland trending NW-SE across Jutland, from Ringkøbing in the west to Billund in central Jutland. East of Billund the main delta bends northwards, and the eastern limit follows a line from the town of Give northwards. The estimated size of the delta is in the order of $10000 \mathrm{~km}^{2}$ whereas its thickness varies from $300 \mathrm{~m}$ in the North Sea to less than $100 \mathrm{~m}$ in central Jutland. Associated spit complexes that outcrop in eastern Jutland are rarely thicker than $30 \mathrm{~m}$. In some areas the seismic data are characterised by strongly southwards-dipping reflectors (clinoforms; Fig. 3B). Correlation of seismic data with borehole information reveals that where the clinoforms are distinct, they represent massive sands (Fig. 4); north of Billund, the massive sands may be up to $75 \mathrm{~m}$ thick. The Billund delta complex is characterised by a pinchout distance of $c .2 \mathrm{~km}$ which in recent delta systems is a characteristic feature of wave-dominated deltas (cf. Løseth \& Helland-Hansen 2001).

\section{Study of boreholes}

A number of recent, deep boreholes have penetrated the Billund delta (Fig. 4). These show that the delta comprises a coarsening-upwards succession of medium- to coarse-grained sand with gravel and thin clay layers locally present. A very coarse-grained layer succeeded by a thinning-upwards succession in the Store Vorslunde borehole indicates that some of the sand was deposited in channels. The thickness of the delta sand varies from $40 \mathrm{~m}$ in Store Vorslunde to $50 \mathrm{~m}$ in the Billund borehole. However, the Eg-3 well (Fig. 1), an old deep exploration well, indicates that up to $100 \mathrm{~m}$ of sand may be present.

\section{Study of outcrops}

A spit system corresponding to the down-drift part of the Billund delta outcrops along the fjords in eastern Jutland (Fig. 5; Friis et al. 1998). These deposits are known as the Vejle Fjord Formation (Fig. 2). During the last five years these outcrops have been relatively well exposed, and new sequence stratigraphic, biostratigraphic and sedimentological studies have been carried out indicating that a major NW-SE-trending spit was located near the southern part of Vejle Fjord. North of the spit, organic-rich, fine-grained sediments were laid down in a lagoon. Sand-rich lagoonal sediments were deposited near inlets, e.g. at Dykær. South of the
$S$

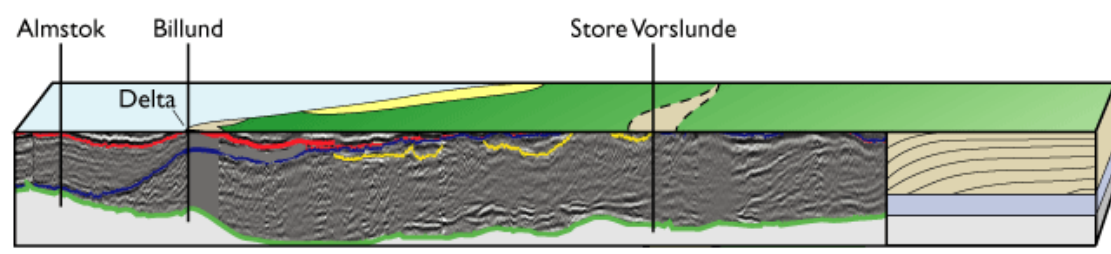

Fig. 5. Block diagram showing the depositional model of the Billund delta. In the upper block diagram the seismic panel shows a prograding delta and the pinchout between the Billund and Almstok wells. The lower diagram illustrates data from outcrops and wells indicating the presence of a spit complex. Note that the spit complex correlates with the delta front at Store Vorslunde. Seismic data courtesy of COWI A/S

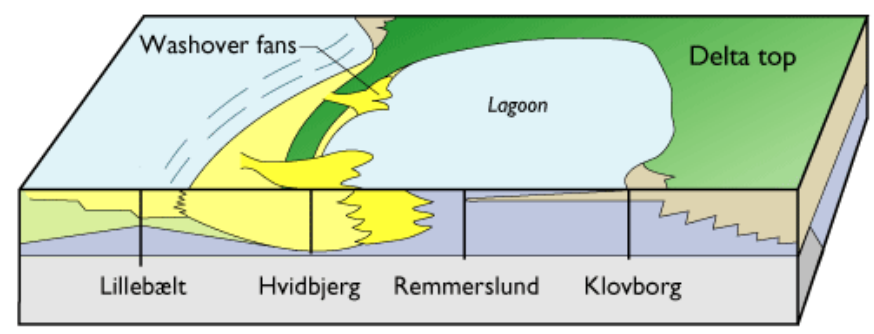

Delta deposits

Lagoonal deposits $\square$ Marine sand $\square$ Marine mud




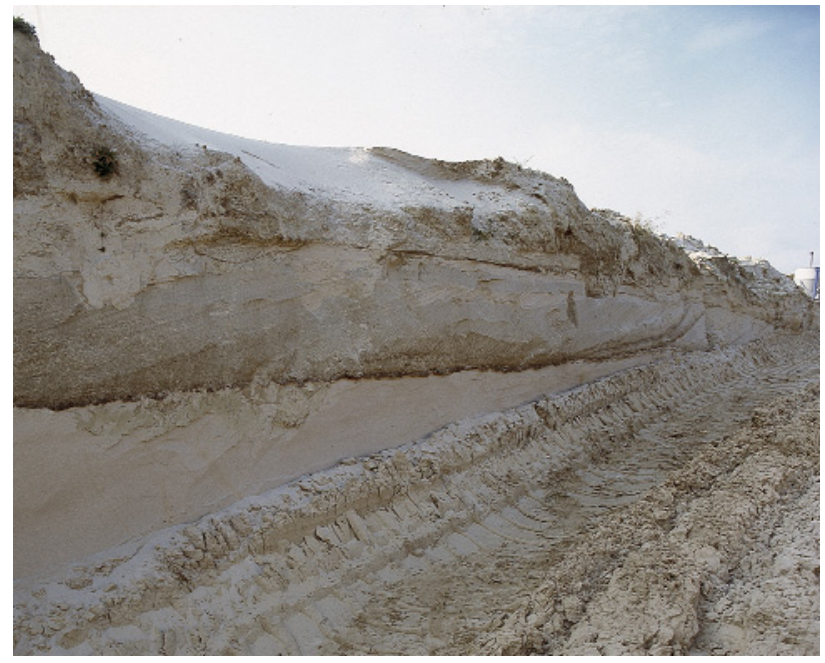

Fig. 6. Tidal sandstone deposits from an ebb-dominated delta succession associated with a spit complex, deposited down-drift from the main Billund delta. Pjedsted sandpit, for location see Fig. 1. Width of track approx. $50 \mathrm{~cm}$.

spit, ebb-dominated tidal deltas were deposited; examples of these are exposed in a sandpit at Pjedsted (Fig. 6). At Lillebælt, upper and lower shoreface sediments were deposited, and are excellently exposed in coastal cliffs at the old Lillebælt bridge (Lillebæltsbro) on Funen and at Børup (Fig. 1). The sedimentological study of the Vejle Fjord Formation indicates that the sediments were laid down in a wave-dominated depositional environment with some tidal influence (Rasmussen et al. 2002).

\section{Future perspectives}

The Billund delta may be one of the most important future aquifers for drinking water in western and central Jutland. Furthermore, the excellent seismic data and the good outcrops in eastern Jutland make it possible to use the Billund delta as a good analogue for Jurassic reservoir rocks in the Central and Viking Grabens of the North Sea.

\section{References}

Dybkjær, K. \& Rasmussen, E.S. 2000: Palynological dating of the Oligocene-Miocene successions in the Lille Bælt area, Denmark. Bulletin of the Geological Society of Denmark 47, 87-103.

Friis, H., Mikkelsen, J. \& Sandersen, P. 1998: Depositional environment of the Vejle Fjord Formation of the Upper Oligocene - Lower Miocene of Denmark: a back island/barrier-protected depositional complex. Sedimentary Geology 17, 221-244.

Larsen, G. \& Dinesen, A. 1959: Vejle Fjord Formation ved Brejning: sedimenterne og foraminiferfaunaen (oligocæn-miocæn). Danmarks Geologiske Undersøgelse II. Række 82, 114 pp.

Løseth, T.M. \& Helland-Hansen, W. 2001: Predicting the pinchout distance of shoreline tongues. Terra Nova 13, 241-248.

Nygaard, E., Ernstsen, V., Jacobsen, C.S., Jacobsen, O.H., Juhler, R.K., van der Keur, P., Olesen, S.E., Rasmussen, J., Rosenberg, P. \& Vosgerau, H. 2004: Pesticide leaching in Danish groundwater: identification of vulnerable areas. Geological Survey of Denmark and Greenland Bulletin 4, 25-28 (this volume).

Rasmussen, E.S. 1995: Vejle Fjord Formation: clay mineralogy and geochemistry. Bulletin of the Geological Society of Denmark 42, 57-67.

Rasmussen, E.S., Dybkjær, K. \& Piasecki, S. 2002: Miocene depositional systems of the eastern North Sea Basin, Denmark. Development of sedimentological and stratigraphical principles in modern sedimentology. Danmarks og Grønlands Geologiske Undersøgelse Rapport 2002/89, 131 pp.

\section{Authors' address}

Geological Survey of Denmark and Greenland, Øster Voldgade 10, DK-1350 Copenhagen K, Denmark. E-mail: esr@geus.dk 